\title{
The "Achilles' Heel" of Cancer and Its Implications for the Development of Novel Immunotherapeutic Strategies
}

\author{
Kroopa Joshi, ${ }^{1,2}$ Benjamin M. Chain, ${ }^{3}$ Karl S. Peggs, ${ }^{1}$ and Sergio A. Quezada ${ }^{1}$ \\ ${ }^{1}$ Cancer Immunology Unit, University College London Cancer Institute, London WC1E 6BT, United Kingdom \\ ${ }^{2}$ Department of Medical Oncology, The Royal Marsden NHS Foundation Trust, London SW3 6JJ, \\ United Kingdom \\ ${ }^{3}$ Division of Infection and Immunity, University College London, London WC1E 6BT, United Kingdom \\ Correspondence: k.peggs@ucl.ac.uk; s.quezada@ucl.ac.uk
}

Over the last century, scientists have embraced the idea of mobilizing antitumor immune responses in patients with cancer. In the last decade, we have seen the rebirth of cancer immunotherapy and its validation in a series of high profile clinical trials following the discovery of several immune-regulatory receptors. Recent studies point toward the tumor mutational load and resulting neoantigen burden as being crucial to tumor cell recognition by the immune system, highlighting a potentially targetable Achilles' heel in cancer. In this review, we explore the key mechanisms that underpin the recognition of cancerous cells by the immune system and discuss how we may advance immunotherapeutic strategies to target the cancer mutanome to stimulate tumor-specific immune responses, ultimately, to improve the clinical outcome for patients with cancer.

$T^{\mathrm{h}}$ he concept of cancer immunotherapy originates from observations made by William Coley in the late 19th century (Fig. 1) (Coley 1991). He documented tumor regression in patients with acute bacterial infections, and proceeded to test bacterial extracts, referred to as "Coley's toxins," in patients with bone and soft tissue sarcomas. Despite the encouraging results reported by Coley, a lack of understanding with regards to the mechanism of action of these toxins in conjunction with the emergence of radiotherapy as a treatment modality led to a decline in the use of Coley's toxin. Subsequent research in cancer immunology, however, led to the development and evaluation of several novel immune-therapeutics, namely interleukin-2 (IL-2), interferon gamma (IFN $\gamma$ ), tumor necrosis factor (TNF) and numerous cancer vaccines.

Although several of these therapeutic strategies produced interesting results in patients with solid cancers, the clinical responses were often short-lived and limited to a small fraction of treated patients. The advent of T-cell checkpoint molecule inhibitors has revolutionized the therapeutic landscape for patients, enthusing scientists globally to better understand the basic mechanisms that underpin the recognition of cancerous cells by the endogenous im-

Editors: Charles Swanton, Alberto Bardelli, Kornelia Polyak, Sohrab Shah, and Trevor A. Graham

Additional Perspectives on Cancer Evolution available at www.perspectivesinmedicine.org

Copyright (C) 2018 Cold Spring Harbor Laboratory Press; all rights reserved; doi: 10.1101/cshperspect.a027086

Cite this article as Cold Spring Harb Perspect Med 2018;8:a027086 
K. Joshi et al.
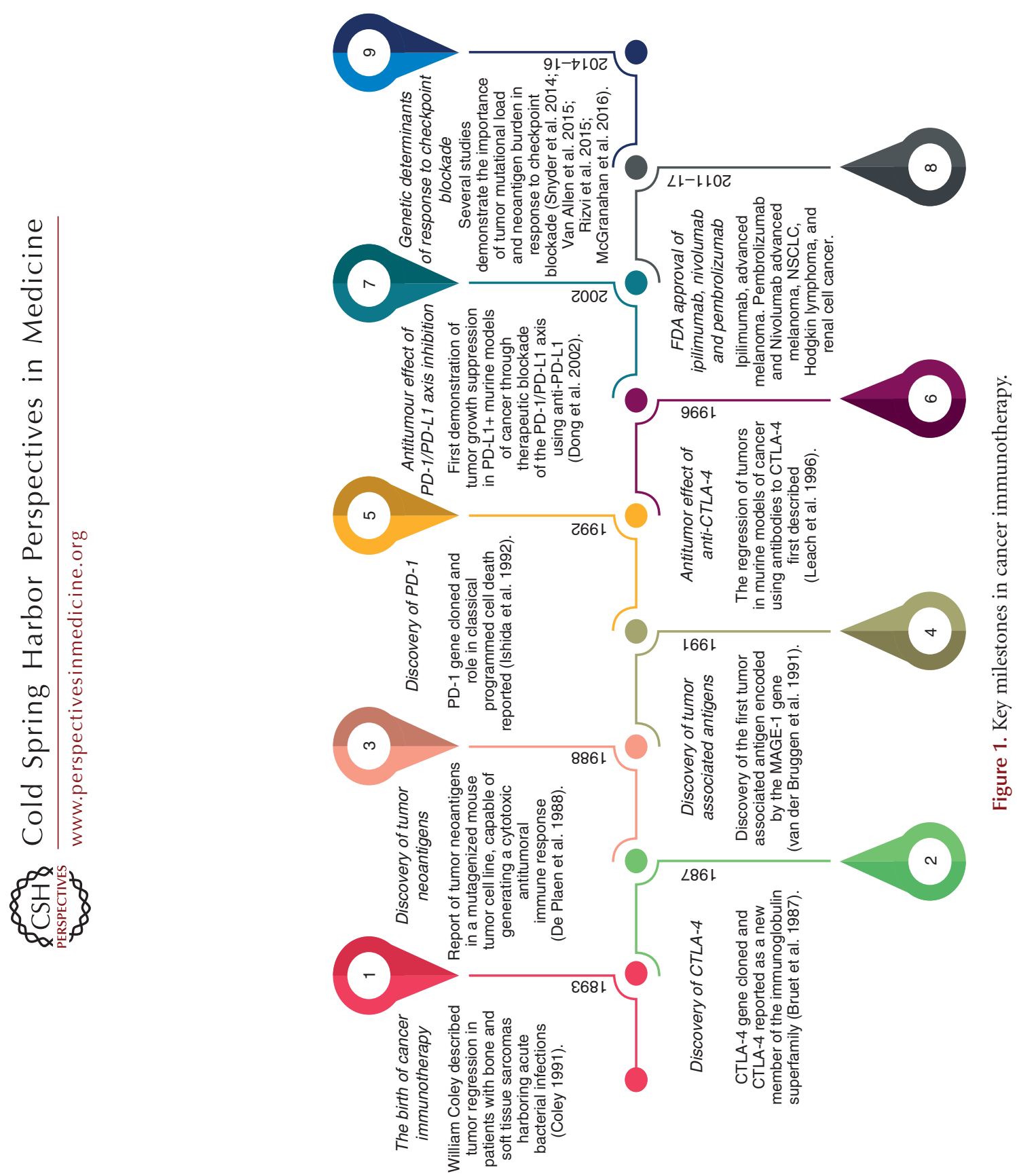
mune system. It is evident from published data to date that the tumor mutational load and the consequent generation of neoantigens are one of the important components of an effective antitumoral immune response, representing the Achilles' heel of cancerous cells. Immunotherapeutic strategies, for example cancer vaccines or adoptive cellular therapy, targeted toward tumor neoantigens in combination with checkpoint molecule inhibitors provide a means of delivering a clinically valuable antitumoral effect through enhancement and activation of tumor-specific immune responses.

\section{CLINICAL SUCCESSES OF IMMUNE CHECKPOINT THERAPIES}

A significant amount of basic and translational research has been directed toward gaining a better understanding of how the immune response to cancer is regulated. A key inflection point in the history of cancer immunotherapy was the discovery of an immune receptor expressed at high levels by in vitro activated T cells, cytotoxic T lymphocyte-associated antigen 4 (CTLA-4) (Brunet et al. 1987). Although its function was elusive at first, a number of experiments showed the role of CTLA-4 as a co-inhibitory receptor, responsible for the down-regulation of T-cell activity. In the mid-1990s, several groups proposed that CTLA-4 would act as an immune checkpoint restricting the activity of tumor reactive T cells (Walunas et al. 1994; Krummel and Allison 1995, 1996; Krummel et al. 1996; Lee et al. 1998; Mokyr et al. 1998). Inhibition of T-cell proliferation and IL-2 secretion was mediated following CTLA-4 activation and subsequent data showed the effective rejection of tumors in murine models of cancer using antibodies against CTLA-4 (Krummel and Allison 1995; Leach et al. 1996). Further evaluation of mechanism of action has suggested that the antibodies can act both by blocking inhibitory signaling on effector $\mathrm{T}$ cells and by driving Fc $\gamma$ receptor-mediated depletion of tumor infiltrating regulatory $\mathrm{T}$ cells expressing higher levels of CTLA-4 than effector T cells (Quezada et al. 2006, 2008; Peggs et al. 2009; Simpson et al. 2013).
These key studies gave rise to the concept of immune regulation of $\mathrm{T}$ cells involved in antitumoral immunity, mediated by CTLA-4, leading to the clinical development of antibodies targeting CTLA-4. Ipilimumab, a fully humanized monoclonal antibody to CTLA-4, was shown to deliver durable responses in patients with advanced melanoma in several clinical trials, leading to its approval by the U.S. Food and Drug Administration (FDA) for the treatment of metastatic melanoma in 2011.

The discovery of a second T-cell co-inhibitory molecule of the B7 family, programmed death receptor 1 (PD-1) (Ishida et al. 1992) and its ligand, programmed death receptor ligand 1 (PD-L1) (Freeman et al. 2000), was later followed by data showing that blockade of the PD-1/PD-L1 axis using monoclonal antibodies could affect similar antitumor immune responses in mice with established tumors (Dong et al. 2002). The secretion of inflammatory cytokines by infiltrating lymphocytes, for example, IFN $\gamma$, leads to the up-regulation of PD-L1 on the tumor cell surface and surrounding tissues, resulting in the inhibition of T-cell activity as a result of PD-1/PD-L1 interaction resulting in tumor immune evasion, a process referred to as "adaptive immune resistance" (Pardoll 2012).

Numerous trials of anti-PD- 1 and anti-PDL1 therapies have shown impressive clinical responses with survival benefit in a variety of solid (Borghaei et al. 2015; Garon et al. 2015; Larkin et al. 2015; Motzer et al. 2015; Robert et al. 2015a,b; Fehrenbacher et al. 2016; Ferris et al. 2016; Herbst et al. 2016; Reck et al. 2016; Rosenberg et al. 2016; Seiwert et al. 2016; Bellmunt et al. 2017; Rittmeyer et al. 2017; Sharma et al. 2017) and haematological cancers (Ansell et al. 2015; Moskowitz et al. 2016), transforming the outlook for a large number of patients. Currently, nivolumab and pembrolizumab, both monoclonal antibodies to PD-1, are licensed by the FDA for use in advanced melanoma, metastatic nonsmall cell lung cancer (NSCLC), metastatic squamous cell head and neck cancers, and Hodgkin lymphoma (Table 1).

The success of both anti-PD-1 and antiCTLA-4 therapy has paved the way for the clin- 
K. Joshi et al.

Table 1. Current FDA approved checkpoint molecule inhibitors and clinical trial references

FDA approved checkpoint molecule antibodies

Nivolumab (PD-1)

Metastatic melanoma (Robert et al. 2015a)

Metastatic NSCLC (Borghaei et al. 2015)

Hodgkin lymphoma (Ansell et al. 2015)

Metastatic RCC (Motzer et al. 2015)

Metastatic squamous cell carcinoma of the head and neck (Ferris et al. 2016)

Locally advanced or metastatic urothelial carcinoma (Sharma et al. 2017)

Pembrolizumab (PD-1)

Metastatic melanoma (Robert et al. 2015b)

Metastatic NSCLC (Reck et al. 2016)

Metastatic squamous cell carcinoma of the head and neck (Seiwert et al. 2016)

Hodgkin lymphoma (Moskowitz et al. 2016)

Atezolizumab (PD-L1) Locally advanced or metastatic urothelial carcinoma (Rosenberg et al. 2016)

Metastatic NSCLC (Fehrenbacher et al. 2016; Rittmeyer et al. 2017)

Ipilimumab (CTLA-4) Metastatic melanoma (Hodi et al. 2010)

Ipilimumab and nivolumab Metastatic melanoma (Larkin et al. 2015)

(CTLA-4 and PD-1)

ical development of a large number of immunomodulatory antibodies, creating much excitement in the field of cancer immunotherapy. However, an important question regarding the precise nature of the antigens that are recognized by heavily regulated lymphocytes remains to be fully answered.

\section{CHARACTERIZATION OF ANTIGENS RECOGNIZED BY TUMOR INFILTRATING LYMPHOCYTES}

Tumor antigens have typically been classified into two main categories based on their distribution within tissues. Tumor-associated antigens (TAAs) include tissue differentiation markers (e.g., MART-1, gp100, TRP-1, and TRP-2 proteins) expressed both on normal tissue and tumor cells and cancer-testes antigens (e.g., NY-ESO-1 and MAGE-A3) expressed in germ cells and tumor cells (for review, refer to Kawakami et al. 2004). In contrast, mutations that are found exclusively within cancer cells that are not present in normal tissue give rise to tumor-specific antigens often referred to as tumor neoantigens.

In 1991, work done by van der Bruggen et al. (1991) revealed the presence of a gene encoding the antigen MAGE-1, found within melanoma cells and not in most normal tissues, recognized by cytotoxic lymphocytes in a pa- tient with melanoma. This gave rise to the concept of TAAs, following which the discovery of several other key self-antigens encoded by gp100, MART-1, and tyrosinase occurred (Brichard et al. 1993; Coulie et al. 1994; Kawakami et al. 1994). The identification of TAAs, particularly the finding that these were often shared between patients, drew much attention in the field of cancer immunology leading to the development of adoptive cellular therapies and cancer vaccines targeted against TAAs.

Several research groups, including those of Thierry Boon and Hans Schreiber, have shown the role of tumor neoantigens in promoting effective antitumor immunity. The mutagenization of a mouse tumor cell line (P815 tumor cell line) led to a highly immunogenic tumor cell variant that was rejected by syngeneic mice because of the expression of novel mutated antigens, resulting in a cytotoxic antitumoral immune response (De Plaen et al. 1988). A subsequent study showed the presence of a $\mathrm{CD} 8^{+}$ T-lymphocyte response to a peptide arising from a tumor-specific somatic mutation in the coding region of a nucleic acid helicase, p68, in an ultraviolet (UV) light-induced murine tumor (Dubey et al. 1997). In a separate study, $\mathrm{CD}^{+}{ }^{\mathrm{T}}$ lymphocytes were shown to recognize unique tumor neoantigens expressed exclusively within the tumor cells of an UV light-induced murine model of cancer (Monach et al. 1995). 
These studies were bridged to human data by the demonstration of tumor infiltrating lymphocytes capable of recognizing a tumor neoantigen encoded by mutated cyclin-dependent kinase 4 (CDK4) in a human melanoma specimen (Wölfel et al. 1995), and of others capable of recognizing antigen arising from a mutated $\beta$-catenin gene exclusively found within melanoma cells (Robbins et al. 1996). A separate study showed the presence of cytotoxic lymphocytes specific to a neoantigen arising from mutated CASP-8 in a squamous cell carcinoma of the oral cavity (Mandruzzato et al. 1997). These findings provided initial support that, in humans, tumor-specific $\mathrm{T}$ cells, which we refer to as neoantigen reactive $\mathrm{T}$ cells (NARTs), have the capacity to recognize neoantigens found exclusively within the tumor.

Taken together, data from these studies support the concept of antitumoral immune responses against antigens that are expressed as a consequence of the accumulation of mutations within tumors. One can also infer from these studies that the level of tumoral mutational burden may confer a survival advantage through the expression of neoantigens that are recognized by the immune system, driving a specific antitumoral immune response. Given that neoantigens are found to occur as a result of mutations that are largely "private" and unique to individual tumors, the therapeutic targeting of neoantigens represented a huge translational challenge during the 1990s, in an era in which next-generation sequencing was not as economical and readily available as it is today, halting the development of personalized medicine. This led to a shift in the focus of cancer immunology research toward tumor antigens that were shared between tumors of different patients across varied tumor types, leading to increasing focus on TAAs.

\section{THE RENAISSANCE OF TUMOR NEOANTIGENS IN CANCER IMMUNOLOGY}

The renaissance of neoantigens has been facilitated by improvements in next-generation sequencing techniques and bioinformatics pipelines, including the development of neoantigen peptide prediction algorithms, on a background of disappointing results from immunotherapeutic strategies targeted against TAAs.

In the last 15 years, a number of studies have pointed toward the importance of neoantigendirected immune responses. In one study, T-cell responses toward neoantigens arising from five tumor-specific mutations were shown to predominate over those against TAAs within the same patient (Lennerz et al. 2005). A separate study showed the presence of neoantigen reactive $\mathrm{CD}^{+}$cells in the tumors of patients with melanoma (Linnemann et al. 2015). Importantly, neoantigen-specific $\mathrm{T}$ cells have also been detected in the peripheral blood of patients with melanoma (Cohen et al. 2015). Taken together, data from these studies support the role of neoantigens in antitumor immunity; however, further studies directly comparing the relative contributions of neoantigens versus TAAs in the antitumoral immune response are necessary.

Further work in murine models supported the development of personalized immunotherapies for patients with cancer. Next-generation sequencing and major histocompatibility complex (MHC) class I in silico prediction methods were used to identify tumor-specific mutations and corresponding predicted peptides in a murine model of MCA-induced fibrosarcoma. A predicted neoantigen arising from mutated spectrin $\beta-2$ was subsequently shown to be a key mediator of the antitumoral T-cell response. Furthermore, the investigators reported that the immunological editing of the cancers in these mice occurred as a result of a selection process dependent on T cells (Matsushita et al. 2012). The concept of the immunological editing of cancers relates to earlier work done by the same investigators (Koebel et al. 2007) and comprises of three key components (for review, see Dunn et al. 2002). This includes the elimination of tumors through cancer immunosurveillance, maintenance of cancer in an equilibrium state as a result of the endogenous immune response and lastly, tumor escape. Tumors may evade immune-mediated destruction as a result of the clonal evolution of cancerous cells with preferential expansion of tumoral 
K. Joshi et al.

subclones lacking immunogenicity or those with the ability to suppress immune responses leading to tumor progression.

In a separate study, next-generation sequencing was used to identify tumor-specific nonsynonymous mutations in melanoma cells derived from a B16F10 mouse model. Importantly, in mice harboring tumors, immunization with peptides encoded for by nonsynonymous mutations predicted to bind to MHC class I molecules by in silico prediction algorithms lead to tumor control (Castle et al. 2012). The importance of MHC class II presented neoantigens and tumor-reactive $\mathrm{CD} 4^{+}$cells has also been reported (Kreiter et al. 2015). In this study, Kreiter and colleagues proposed a bioinformatics method through which polyneo-epitope messenger RNA (mRNA) vaccines could be synthesized based on both MHC class II predicted binding and expression levels of tumor mutations. They successfully showed that such approaches used to generate vaccines targeted against $\mathrm{CD} 4{ }^{+}$neoantigens resulted in a potent antitumor effect in three separate murine models of cancer. Interestingly, through use of the same bioinformatic prediction algorithm, a large number of mutations giving rise to neoantigens predicted to bind to MHC class II in human cancers were also found.

Previous preclinical data has shown the ability of tumor-reactive $\mathrm{CD} 4^{+}$cells to develop cytotoxic activity leading to tumor rejection in murine B16/BL6 tumor models (Quezada et al. 2010). Moreover, durable clinical responses to adoptively transferred NY-ESO-1specific or tumor neoantigen-specific $\mathrm{CD} 4^{+}$cells were reported in metastatic melanoma (Hunder et al. 2008) and cholangiocarcinoma (Tran et al. 2014), respectively. Together, these studies provide support for the role of $\mathrm{CD} 4^{+}$effector cells in the adaptive antitumoral immune response. This may be achieved through either direct cytotoxic activity in the context of MHC class II expressing tumors and/or facilitation of $\mathrm{CD} 8^{+}$ T-cell expansion and effector function to promote immune-mediated tumor cell destruction.

The studies discussed above provide insight into the successful application of next-generation sequencing techniques and neoantigen prediction algorithms to identify and characterize TAAs and tumor neoantigens presented by MHC class I and class II molecules. Moreover, they highlight the crucial role of $\mathrm{CD} 4^{+} \mathrm{T}$ cells in generating effective antitumoral immune responses and underline the importance of further research in this area, particularly for the development of $\mathrm{CD} 4{ }^{+}$targeted immunotherapeutic strategies for patients with cancer.

\section{THE INTERPLAY BETWEEN NEOANTIGEN REACTIVE T CELLS AND THE RESPONSE TO CANCER IMMUNOTHERAPY}

Several groups have shown the presence of neoantigen driven T-cell responses in human cancers responding to either adoptive cellular therapy and/or immunomodulatory antibodies. The persistence of neoantigen-specific T-cell clones recognizing mutated growth arrested-specific gene 7 (GAS7) and glyceraldehyde-3-phosphate dehydrogenase (GAPDH) in the peripheral blood of a patient with stage IV melanoma reported to have a complete response after adoptive transfer of autologous tumor infiltrating lymphocytes was inferred to be indicative of their role in maintaining a clinical response (Zhou et al. 2005). Moreover, neoantigen reactivity of adoptively transferred $\mathrm{T}$ cells was elucidated in three patients with advanced melanoma with objective responses to adoptive cellular therapy (Robbins et al. 2013), and neoantigen reactive $\mathrm{CD} 4^{+} \mathrm{T}$ cells were identified in a patient with metastatic cholangiocarcinoma displaying a response to adoptive cellular therapy (Tran et al. 2014). Furthermore, neoantigen reactive $\mathrm{CD} 8^{+} \mathrm{T}$-cell responses were also reported in a patient with advanced melanoma responsive to anti-CTLA4 therapy (van Rooij et al. 2013). These clinical data provide evidence for the role of $\mathrm{CD}^{+}$and $\mathrm{CD}^{+}{ }^{+} \mathrm{T}$ cells in recognizing tumor neoantigens and suggest that immunomodulatory antibodies may act by enhancing the activity of NARTs to achieve tumor control.

Several studies during the last few years have highlighted the close interplay that exists between the genomic landscape of tumors and the clinical response to checkpoint blockade. 
The Development of Immunotherapeutic Strategies for Cancer

Patients with tumors of a relatively high mutational load were found to have a favorable clinical outcome following anti-CTLA-4 therapy (Snyder et al. 2014). Similarly, patients with metastatic melanoma categorized as deriving clinical benefit from anti-CTLA- 4 therapy were found to have a significantly higher tumor mutational load compared with those patients with minimal or no clinical benefit from the drug (Van Allen et al. 2015). Moreover, in patients with NSCLC treated with anti-PD-1 therapy, a higher nonsynonymous mutational load and neoantigen burden was associated with durable clinical responses and progression free survival. Furthermore, neoantigen-specific $\mathrm{CD}^{+}$T-cell responses and tumor regression were seen concurrently in a responding patient (Rizvi et al. 2015).

Taken together, data from these studies highlight the intricate relationship that exists between the tumor mutational and neoantigen landscape and the antitumoral immune response. Furthermore, they shed light on the mechanistic activity of immunomodulatory antibodies, illustrating how anti-CTLA-4 and antiPD-1 therapy may be used to counteract the immune regulation of NARTs. It is important to note, however, that the relationship between tumor mutational load and response to checkpoint blockade is not absolute; metastatic renal cell carcinoma (RCC) has a moderate tumoral mutational load and is associated with durable responses to anti-PD-1 therapy (Alexandrov et al. 2013; Motzer et al. 2015). Moreover, colorectal cancer is not typically considered to be a cancer with a high mutational load (Alexandrov et al. 2013); however, clinical benefit from antiPD-1 therapy is reported in a subgroup of these patients (Le et al. 2015). Patients with DNA mismatch repair deficiency (MMR) were shown to have an increased clinical response to anti-PD-1 therapy likely related to an increased mutational and neoantigen load arising from MMR deficiency in these patients (Le et al. 2015).

\section{INTRATUMORAL HETEROGENEITY AND ANTITUMOR IMMUNITY}

The concept of genetic intratumoral heterogeneity is well documented in a variety of solid and haematological cancers (Campbell et al. 2010; Anderson et al. 2011; Gerlinger et al. 2012; Martinez et al. 2013; Bolli et al. 2014; McGranahan et al. 2015). Nonsynonymous mutations present in every tumor cell give rise to clonal neoantigens that occur early in tumor evolution and are therefore ubiquitously expressed within tumor tissues. In contrast, subclonal or "branch" mutations resulting in the expression of subclonal neoantigens occur later, and so are localized to specific tumor cell subsets.

The impact of intratumoral neoantigen heterogeneity on the antitumor immune response has been investigated more recently. A strong relationship between the level of clonal neoantigen burden and overall survival was found in patients with lung adenocarcinoma from analysis of sequencing data within The Cancer Genome Atlas (TCGA) database. More indepth analysis revealed the up-regulation of immune-related genes including CD8, granzyme, IFN $\gamma$, PD-1, LAG-3, PD-L1, and PD$\mathrm{L} 2$, in patients with a high burden of clonal neoantigens and a relatively low fraction of subclonal neoantigens, indicative of an active antitumor immune response within the tumor tissues of these patients. Of note, $\mathrm{CD}^{+}{ }^{+} \mathrm{T}$-cell responses to neoantigens were detected in two patients with early stage NSCLC with a comparable number of predicted neoantigens but markedly different levels of intratumoral neoantigen heterogeneity. NARTs identified by MHC-multimer analysis were found to have increased levels of PD-1 and LAG-3 expression on their cell surface indicative of immune regulation of these cells (McGranahan et al. 2016).

Analysis of genomic sequencing data from anti-PD-1 (Rizvi et al. 2015) or anti-CTLA-4 (Snyder et al. 2014) treated cohorts indicated that a high predicted clonal neoantigen burden and low neoantigen heterogeneity in NSCLC and metastatic melanoma was associated with favorable clinical outcomes (McGranahan et al. 2016). This study highlights fundamental differences in the effectiveness of the antitumoral immune response driven by clonal versus subclonal neoantigens. A recent study exploring the tumor neoantigen landscape in matched NSCLC tumor specimens pre and post anti- 
K. Joshi et al.

PD-1 or dual anti-PD-1/anti-CTLA-4 therapy showed genomic and immune-mediated loss of tumor neoantigens in resistant tumors (Anagnostou et al. 2017). Moreover, immunotherapy resistance has been shown to correlate with tumor aneuploidy; patients with increased tumoral somatic copy number alterations were found to have reduced survival following antiCTLA-4 therapy compared with those with reduced tumor aneuploidy (Davoli et al. 2017). A lack of cytotoxic immune infiltration in tumors with high levels of tumor aneuploidy may contribute to the reduced survival observed in these anti-CTLA- 4 treated patients.

The studies discussed above provide insight into firstly, the importance of clonal neoantigens in predicting response to checkpoint blockade and secondly, the potential impact of checkpoint blockade and/or tumor aneuploidy in the immunological editing of neoantigens that may in fact lead to tumor immune evasion. Therapeutically targeting a wide repertoire of clonal neoantigens may theoretically provide an effective method of targeting the cancer mutanome although this is yet to be proven (Fig. 2).

\section{T-CELL RECEPTOR REPERTOIRE AND CLONALITY IN CANCER}

The repertoire of antigen-specific $\mathrm{T}$ cells is generated in the thymus during the process of $\mathrm{T}$-cell differentiation as a result of somatic recombination of both $\alpha$ and $\beta$ chains of the T-cell receptor (TCR), followed by central deletional tolerance of the most highly self-reactive $\mathrm{T}$ cells. The somatic rearrangement of either $\mathrm{V}$ and $J$ segments or $V, D$, J segments of $\alpha$ and $\beta$ chains respectively, gives rise to the highly variable complementarity determining region 3 (CDR3) of the TCR, key in determining the antigen specificity of individual T-cell clones.

The level of mutational burden and genomic heterogeneity shown in a variety of solid cancers could be reflected in the clonality and repertoire of tumor-reactive lymphocytes found within the tumor microenvironment,

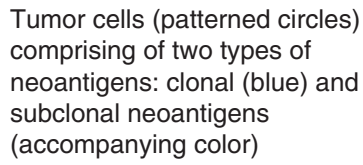

Tumor cells (patterned circles) comprising of two types of neoantigens: clonal (blue) and subclonal neoantigens (accompanying color)

Multipeptide vaccine or adoptive cellular therapy targeting subclonal or clonal neoantigens

Tumor neoantigen landscape following subclonal or clonal neoantigen targeted immunotherapy. Gray circles indicative of eliminated tumor clones

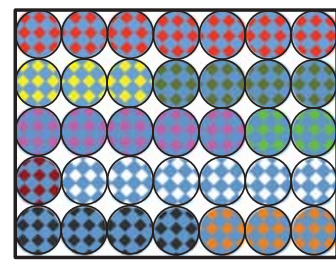

Subclonal neoantigen targeted therapy

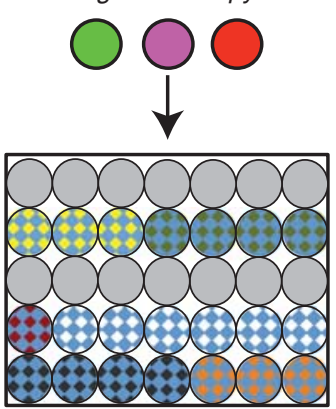

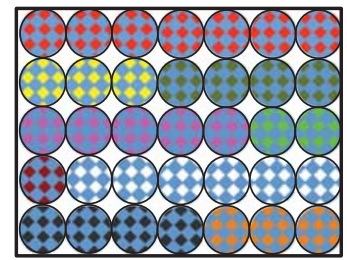

Clonal neoantigen targeted therapy

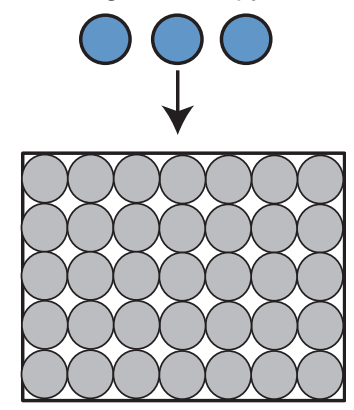

Figure 2. Immunotherapeutic targeting of cancer's Achilles' heel. Tumor cells depicted as patterned circles comprising of two types of neoantigens. Clonal neoantigens found in all cancerous cells are shaded blue. Subclonal neoantigens are represented by accompanying patterned colors within each circle. Multipeptide vaccine or adoptive cellular therapy targeting subclonal antigens may result in selection for tumor cell subclones (bottom left) whereas clonally targeted neoantigen immunotherapy has the potential to achieve optimal tumor elimination (bottom right). 
The Development of Immunotherapeutic Strategies for Cancer

but data is currently limited. Tumors with a high mutational load and resulting neoantigen burden may give rise to a more diverse intratumoral T-cell repertoire caused by the large number of antigens presented to the immune system. In line with this, an association between T-cell diversity and mutational load has previously been reported through the analysis of reconstructed CDR3 regions from RNAseq data of samples within the TCGA database ( $\mathrm{Li}$ et al. 2016).

Previous studies examining the effects of anti-CTLA-4 therapy on the TCR repertoire have shown peripheral blood TCR repertoire diversification following therapy (Robert et al. 2014) and improved overall survival in patients who maintained highly abundant TCR clones present in the blood before commencement of anti-CTLA-4 therapy (Cha et al. 2014). Anti-CTLA-4 therapy has also been described to significantly increase the number of newly detected $\mathrm{CD}^{+}{ }^{+}$melanoma-specific T-cell clones (Kvistborg et al. 2014).

The response to anti-PD-1 therapy in metastatic melanoma has previously been associated with a more clonal and less diverse intratumoral TCR repertoire at baseline in melanoma specimens. Furthermore, in responding patients, a significant increase in the number of expanded TCR clones following anti-PD-1 therapy was reported, indicative of an enhanced oligoclonal T-cell response within tumors of patients with metastatic melanoma (Tumeh et al. 2014).

Heterogeneity in the repertoire of $\mathrm{T}$ cells infiltrating different regions of clear-cell RCC has been shown using multiregion TCR sequencing (Gerlinger et al. 2013), and spatial heterogeneity of TILs infiltrating oesophageal cancers is also documented (Chen et al. 2016). Interestingly, in the latter study, deeper analysis limited to the 100 most abundant TCR clones revealed a high degree of overlapping TCRs between tumor regions within each individual patient (Chen et al. 2016). Theoretically, these TCR clones, present across multiple regions of the tumor may expand in response to common antigens found in all tumor regions, although the specificity of tumoral clones seen across multiple regions of a tumor remains to be elucidated.

\section{THERAPEUTIC APPROACHES TO TARGET THE CANCER MUTANOME AND FUTURE PERSPECTIVES}

Vaccination strategies, adoptive cellular therapies or the adoptive transfer of engineered $\mathrm{T}$ cells targeting tumor neoantigens, in conjunction with checkpoint molecule antibodies, represent some of the key avenues for targeting the cancer mutanome that are currently being explored in a number of clinical trials. Clinical trials of personalized neoantigen vaccines $+/-$ checkpoint blockade are recruiting in a variety of solid cancers (Table 2). Early phase trials of neoantigen-based adoptive cellular therapies and trials of engineered $\mathrm{T}$ cells harboring TCRs against neoantigens are eagerly awaited.

As we move closer to achieving our goal of delivering personalized medicine for many of our patients, we must be thorough in our

Table 2. Clinical trials of neoantigen targeted immunotherapy currently open to recruitment

\begin{tabular}{lc}
\hline Trial name & $\begin{array}{c}\text { ClinicalTrials.gov } \\
\text { number }\end{array}$ \\
\hline $\begin{array}{l}\text { A personalized cancer vaccine (NEO-PV-01) with nivolumab for patients with } \\
\text { melanoma, lung cancer, or bladder cancer }\end{array}$ & NCT02897765 \\
$\begin{array}{l}\text { A phase I study with a personalized neoantigen cancer vaccine in melanoma } \\
\text { A phase I personalized neoantigen cancer vaccine with radiotherapy for patients with } \\
\text { MGMT unmethylated, newly diagnosed glioblastoma }\end{array}$ & NCT01970358 \\
$\begin{array}{l}\text { Neoepitope-based personalized vaccine approach in patients with newly diagnosed } \\
\text { glioblastoma }\end{array}$ & NCT02510950 \\
\hline
\end{tabular}

See clinicaltrials.gov. 
K. Joshi et al.

approach. It is clear that such bespoke approaches to target cancers will involve sequencing and identification of tumor-specific mutations, in silico prediction of resulting neoantigen sequences according to individual patient human leukocyte antigen (HLA) types and predicted strength of neoantigen peptide binding to $\mathrm{MHC}$ to guide appropriate selection of neoantigen peptide sequences. Moreover, neoantigen targeted adoptive cellular therapies will rely on information generated from in vitro assays, testing the reactivity of tumor infiltrating lymphocytes stimulated with synthesized peptides. It is critical that we recognize that despite the advances in next-generation sequencing and bioinformatics methods, these techniques are themselves imperfect; the limitations of neoantigen prediction algorithms and verification of whether tumor cells actually express such predicted neoantigens poses a significant challenge. The therapeutic targeting of neoantigens may minimize the risks of toxicities in cancer patients undergoing checkpoint blockade (Zimmer et al. 2016), because these are often related to immune responses to tumor associated self-antigens that may also be expressed in some normal tissues. Nevertheless, the possibility that TCRs may show some degree of cross-reactivity with unrelated self-antigens may still exist.

In the context of neoantigen-targeted vaccine therapy, the expansion of regulatory $\mathrm{T}$ cells following vaccination is a likely possibility, thus combination of vaccines with therapeutic agents that either deplete regulatory $\mathrm{T}$ cells or limit the action of inhibitory cytokines, for example, indoleamine 2,3-dioxygenase (IDO), transforming growth factor beta (TGF- $\beta$ ), or interleukin-10 (IL-10) may be required to achieve successful clinical outcomes. The effectiveness of clonal neoantigen targeted adoptive cellular therapies will rely on infiltration of transferred $\mathrm{T}$ cells into the tumor microenvironment and the use of appropriate combinational strategies to overcome the immune regulation of these cells. The possibility exists that tumor immune escape may occur as a result of tumor resistance to IFN $\gamma$ signaling, as described previously in the context of acquired resistance to anti-PD-1 therapy (Zaretsky et al. 2016). Successful therapeutic strategies of how best to overcome tumor resistance in this context remain to be elucidated. Despite these challenges, however, there is hope for optimism that we may finally have found an exploitable Achilles' heel in our battle against cancer.

\section{ACKNOWLEDGMENTS}

K.J. is funded by The Sam Keen Foundation and UCL/Royal Marsden Hospital National Institute for Health Research (NIHR) Biomedical Research Centres. S.A.Q. is a Cancer Research United Kingdom (CRUK) Senior Cancer Research Fellow and is funded by a CRUK Biotherapeutic Program Grant and a CRUK Senior Cancer Research Fellowship. K.S.P. receives funding from the NIHR Blood and Transplant Research Unit (BTRU) for Stem Cells and Immunotherapies, of which he is the Scientific Director.

\section{REFERENCES}

Alexandrov LB, Nik-Zainal S, Wedge DC, Aparicio SA, Behjati S, Biankin AV, Bignell GR, Bolli N, Borg A, BørresenDale AL, et al. 2013. Signatures of mutational processes in human cancer. Nature 500: 415-421.

Anagnostou V, Smith KN, Forde PM, Niknafs N, Bhattacharya R, White J, Zhang T, Adleff V, Phallen J, Wali N et al. 2017. Evolution of neoantigen landscape during immune checkpoint blockade in non-small cell lung cancer. Cancer Discov 7: 264-276.

Anderson K, Lutz C, van Delft FW, Bateman CM, Guo Y, Colman SM, Kempski H, Moorman AV, Titley I, Swansbury J, et al. 2011. Genetic variegation of clonal architecture and propagating cells in leukaemia. Nature 469: 356.

Ansell SM, Lesokhin AM, Borrello I, Halwani A, Scott EC, Gutierrez M, Schuster SJ, Millenson MM, Cattry D, Freeman GJ, et al. 2015. PD-1 blockade with nivolumab in relapsed or refractory Hodgkin's lymphoma. $N$ Engl J Med 372: 311-319.

Bellmunt J, de Wit R, Vaughn DJ, Fradet Y, Lee JL, Fong L, Vogelzang NJ, Climent MA, Petrylak DP, Choueiri TK et al. 2017. Pembrolizumab as second-line therapy for advanced urothelial carcinoma. $N$ Engl J Med 376: 1015-1026.

Bolli N, Avet-Loiseau H, Wedge DC, Van Loo P, Alexandrov LB, Martincorena I, Dawson KJ, Iorio F, Nik-Zainal S, Bignell GR, et al. 2014. Heterogeneity of genomic evolution and mutational profiles in multiple myeloma. Nat Commun 5: 2997.

Borghaei H, Paz-Ares L, Horn L, Spigel DR, Steins M, Ready NE, Chow LQ, Vokes EE, Felip E, Holgado E, et al. 2015. 
Nivolumab versus docetaxel in advanced nonsquamous non-small-cell lung cancer. $N$ Engl J Med 373: 16271639.

Brichard V, Van Pel A, Wölfel T, Wölfel C, De Plaen E, Lethé B, Coulie P, Boon T. 1993. The tyrosinase gene codes for an antigen recognized by autologous cytolytic $\mathrm{T}$ lymphocytes on HLA-A2 melanomas. J Exp Med 178: 489-495.

Brunet JF, Denizot F, Luciani MF, Roux-Dosseto M, Suzan M, Mattei MG, Golstein P. 1987. A new member of the immunoglobulin superfamily-CTLA-4. Nature 328: 267-270.

Campbell PJ, Yachida S, Mudie LJ, Stephens PJ, Pleasance ED, Stebbings LA, Morsberger LA, Latimer C, McLaren S, Lin ML, et al. 2010. The patterns and dynamics of genomic instability in metastatic pancreatic cancer. Nature 467: 1109-1113.

Castle JC, Kreiter S, Diekmann J, Löwer M, van de Roemer N, de Graaf J, Selmi A, Diken M, Boegel S, Paret C, et al. 2012. Exploiting the mutanome for tumor vaccination. Cancer Res 72: 1081-1091.

Cha E, Klinger M, Hou Y, Cummings C, Ribas A, Faham M, Fong L. 2014. Improved survival with T cell clonotype stability after anti-CTLA-4 treatment in cancer patients. Sci Transl Med 6: 238ra70.

Chen Z, Zhang C, Pan Y, Yu R, Xu C, Chen Z, Lu Z, Ke Y. 2016. T cell receptor $\beta$-chain repertoire analysis reveals intratumour heterogeneity of tumour-infiltrating lymphocytes in oesophageal squamous cell carcinoma. J Pathol 239: 450-458.

Cohen CJ, Gartner JJ, Horovitz-Fried M, Shamalov K, Trebska-McGowan K, Bliskovsky VV, Parkhurst MR, Ankri C, Prickett TD, Crystal JS, et al. 2015. Isolation of neoantigen-specific T cells from tumor and peripheral lymphocytes. J Clin Invest 125: 3981-3991.

Coley WB. 1991. The treatment of malignant tumors by repeated inoculations of erysipelas. With a report of ten original cases. 1893. Clin Orthop Relat Res 262: 3-11.

Coulie PG, Brichard V, Van Pel A, Wölfel T, Schneider J, Traversari C, Mattei S, De Plaen E, Lurquin C, Szikora JP, et al. 1994. A new gene coding for a differentiation antigen recognized by autologous cytolytic T lymphocytes on HLA-A2 melanomas. J Exp Med 180: 35-42.

Davoli T, Uno H, Wooten EC, Elledge SJ. 2017. Tumor aneuploidy correlates with markers of immune evasion and with reduced response to immunotherapy. Science 355: eaaf8399.

De Plaen E, Lurquin C, Van Pel A, Mariamé B, Szikora JP, Wölfel T, Sibille C, Chomez P, Boon T. 1988. Immunogenic $\left(\right.$ tum $^{-}$) variants of mouse tumor P815: Cloning of the gene of tum ${ }^{-}$antigen P91A and identification of the tum $^{-}$mutation. Proc Natl Acad Sci 85: 2274-2278.

Dong H, Strome SE, Salomao DR, Tamura H, Hirano F, Flies $\mathrm{DB}$, Roche PC, Lu J, Zhu G, Tamada K, et al. 2002. Tumor-associated B7-H1 promotes T-cell apoptosis: A potential mechanism of immune evasion. Nat Med 8: 793-800.

Dubey P, Hendrickson RC, Meredith SC, Siegel CT, Shabanowitz J, Skipper JC, Engelhard VH, Hunt DF, Schreiber H. 1997. The immunodominant antigen of an ultraviolet-induced regressor tumor is generated by a somatic point mutation in the DEAD box helicase p68. J Exp Med 185: 695-705.
Dunn GP, Bruce AT, Ikeda H, Old LJ, Schreiber RD. 2002. Cancer immunoediting: From immunosurveillance to tumor escape. Nat Immunol 3: 991-998.

Fehrenbacher L, Spira A, Ballinger M, Kowanetz M, Vansteenkiste J, Mazieres J, Park K, Smith D, Artal-Cortes A, Lewanski C, et al. 2016. Atezolizumab versus docetaxel for patients with previously treated non-small-cell lung cancer (POPLAR): A multicentre, open-label, phase 2 randomised controlled trial. Lancet 387: 1837-1846.

Ferris RL, Blumenschein G, Fayette J, Guigay J, Colevas AD, Licitra L, Harrington K, Kasper S, Vokes EE, Even C, et al. 2016. Nivolumab for recurrent squamous-cell carcinoma of the head and neck. N Engl J Med 375: 1856-1867.

Freeman GJ, Long AJ, Iwai Y, Bourque K, Chernova T, Nishimura H, Fitz LJ, Malenkovich N, Okazaki T, Byrne MC, et al. 2000. Engagement of the PD-1 immunoinhibitory receptor by a novel B7 family member leads to negative regulation of lymphocyte activation. J Exp Med 192: $1027-1034$.

Garon EB, Rizvi NA, Hui R, Leighl N, Balmanoukian AS, Eder JP, Patnaik A, Aggarwal C, Gubens M, Horn L, et al. 2015. Pembrolizumab for the treatment of non-small-cell lung cancer. N Engl J Med 372: 2018-2028.

Gerlinger M, Rowan AJ, Horswell S, Larkin J, Endesfelder D, Gronroos E, Martinez P, Matthews N, Stewart A, Tarpey P, et al. 2012. Intratumor heterogeneity and branched evolution revealed by multiregion sequencing. $N$ Engl J Med 366: 883-892.

Gerlinger M, Quezada SA, Peggs KS, Furness AJ, Fisher R, Marafioti T, Shende VH, McGranahan N, Rowan AJ, Hazell S, et al. 2013. Ultra-deep T cell receptor sequencing reveals the complexity and intratumour heterogeneity of T cell clones in renal cell carcinomas. J Pathol 231: 424432.

Herbst RS, Baas P, Kim DW, Felip E, Pérez-Gracia JL, Han JY, Molina J, Kim JH, Arvis CD, Ahn MJ, et al. 2016. Pembrolizumab versus docetaxel for previously treated, PD-L1-positive, advanced non-small-cell lung cancer (KEYNOTE-010): A randomised controlled trial. Lancet 387: $1540-1550$.

Hodi FS, O'Day SJ, McDermott DF, Weber RW, Sosman JA, Haanen JB, Gonzalez R, Robert C, Schadendorf D, Hassel JC, et al. 2010. Improved survival with ipilimumab in patients with metastatic melanoma. $N$ Engl J Med 363: 711-723.

Hunder NN, Wallen H, Cao J, Hendricks DW, Reilly JZ, Rodmyre R, Jungbluth A, Gnjatic S, Thompson JA, Yee C. 2008. Treatment of metastatic melanoma with autologous $\mathrm{CD} 4^{+} \mathrm{T}$ cells against NY-ESO-1. N Engl J Med 358: 2698-2703.

Ishida Y, Agata Y, Shibahara K, Honjo T. 1992. Induced expression of PD-1, a novel member of the immunoglobulin gene superfamily, upon programmed cell death. EMBO J 11: 3887-3895.

Kawakami Y, Eliyahu S, Delgado CH, Robbins PF, Sakaguchi K, Appella E, Yannelli JR, Adema GJ, Miki T, Rosenberg SA. 1994. Identification of a human melanoma antigen recognized by tumor-infiltrating lymphocytes associated with in vivo tumor rejection. Proc Natl Acad Sci 91: 6458-6462.

Kawakami Y, Fujita T, Matsuzaki Y, Sakurai T, Tsukamoto M, Toda M, Sumimoto H. 2004. Identification of human 
K. Joshi et al.

tumor antigens and its implications for diagnosis and treatment of cancer. Cancer Sci 95: 784-791.

Koebel CM, Vermi W, Swann JB, Zerafa N, Rodig SJ, Old LJ Smyth MJ, Schreiber RD. 2007. Adaptive immunity maintains occult cancer in an equilibrium state. Nature 450: 903-907.

Kreiter S, Vormehr M, van de Roemer N, Diken M, Löwer M, Diekmann J, Boegel S, Schrörs B, Vascotto F, Castle JC, et al. 2015. Mutant MHC class II epitopes drive therapeutic immune responses to cancer. Nature 520: $692-$ 696.

Krummel MF, Allison JP. 1995. CD28 and CTLA-4 have opposing effects on the response of $\mathrm{T}$ cells to stimulation. J Exp Med 182: 459-465.

Krummel MF, Allison JP. 1996. CTLA-4 engagement inhibits IL-2 accumulation and cell cycle progression upon activation of resting T cells. J Exp Med 183: 2533-2540.

Krummel MF, Sullivan TJ, Allison JP. 1996. Superantigen responses and co-stimulation: CD28 and CTLA-4 have opposing effects on $\mathrm{T}$ cell expansion in vitro and in vivo. Int Immunol 8: 519-5023.

Kvistborg P, Philips D, Kelderman S, Hageman L, Ottensmeier C, Joseph-Pietras D, Welters MJ, van der Burg S, Kapiteijn E, Michielin O, et al. 2014. Anti-CTLA-4 therapy broadens the melanoma-reactive $\mathrm{CD} 8^{+} \mathrm{T}$ cell response. Sci Transl Med 6: 254ra128.

Larkin J, Chiarion-Sileni V, Gonzalez R, Grob JJ, Cowey CL, Lao CD, Schadendorf D, Dummer R, Smylie M, Rutkowski P, et al. 2015. Combined nivolumab and ipilimumab or monotherapy in untreated melanoma. $N$ Engl J Med 373: 23-34.

Le DT, Uram JN, Wang H, Bartlett BR, Kemberling H, Eyring AD, Skora AD, Luber BS, Azad NS, Laheru D, et al. 2015. PD-1 blockade in tumors with mismatch-repair deficiency. N Engl J Med 372: 2509-2520.

Leach DR, Krummel MF, Allison JP. 1996. Enhancement of antitumor immunity by CTLA-4 blockade. Science 271: $1734-1736$.

Lee KM, Chuang E, Griffin M, Khattri R, Hong DK, Zhang W, Straus D, Samelson LE, Thompson CB, Bluestone JA. 1998. Molecular basis of T cell inactivation by CTLA-4. Science 282: 2263-2266.

Lennerz V, Fatho M, Gentilini C, Frye RA, Lifke A, Ferel D, Wölfel C, Huber C, Wölfel T. 2005. The response of autologous $\mathrm{T}$ cells to a human melanoma is dominated by mutated neoantigens. Proc Natl Acad Sci 102: 16013 16018.

Li B, Li T, Pignon JC, Wang B, Wang J, Shukla SA, Dou R, Chen Q, Hodi FS, Choueiri TK, et al. 2016. Landscape of tumor-infiltrating $\mathrm{T}$ cell repertoire of human cancers. Nat Genet 48: 725-732.

Linnemann C, van Buuren MM, Bies L, Verdegaal EM, Schotte R, Calis JJ, Behjati S, Velds A, Hilkmann H, Atmioui DE, et al. 2015. High-throughput epitope discovery reveals frequent recognition of neo-antigens by $\mathrm{CD}^{+} \mathrm{T}$ cells in human melanoma. Nat Med 21: 81-85.

Mandruzzato S, Brasseur F, Andry G, Boon T, van der Bruggen P. 1997. A CASP-8 mutation recognized by cytolytic T lymphocytes on a human head and neck carcinoma. J Exp Med 186: 785-793.
Martinez P, Birkbak NJ, Gerlinger M, McGranahan N, Burrell RA, Rowan AJ, Joshi T, Fisher R, Larkin J, Szallasi Z et al. 2013. Parallel evolution of tumour subclones mimics diversity between tumours. J Pathol 230: 356-364.

Matsushita H, Vesely MD, Koboldt DC, Rickert CG, Uppaluri R, Magrini VJ, Arthur CD, White JM, Chen YS, Shea LK, et al. 2012. Cancer exome analysis reveals a T-celldependent mechanism of cancer immunoediting. Nature 482: 400-404.

McGranahan N, Favero F, de Bruin EC, Birkbak NJ, Szallasi Z, Swanton C. 2015. Clonal status of actionable driver events and the timing of mutational processes in cancer evolution. Sci Transl Med 7: 283ra54.

McGranahan N, Furness AJ, Rosenthal R, Ramskov S, Lyngaa R, Saini SK, Jamal-Hanjani M, Wilson GA, Birkbak NJ, Hiley CT, et al. 2016. Clonal neoantigens elicit $\mathrm{T}$ cell immunoreactivity and sensitivity to immune checkpoint blockade. Science 351: 1463-1469.

Mokyr MB, Kalinichenko T, Gorelik L, Bluestone JA. 1998. Realization of the therapeutic potential of CTLA- 4 blockade in low-dose chemotherapy-treated tumor-bearing mice. Cancer Res 58: 5301-5304.

Monach PA, Meredith SC, Siegel CT, Schreiber H. 1995. A unique tumor antigen produced by a single amino acid substitution. Immunity 2: 45-59.

Moskowitz C, Zinzani PL, Fanale MA, et al. 2016. Pembrolizumab in relapsed/refractory classical Hodgkin lymphoma: Primary end point analysis of the Phase 2 Keynote-087 Study. American Society of Haematology 58th Annual Meeting \& Exposition, Abstract 1107. San Diego, CA, December 3-6.

Motzer RJ, Escudier B, McDermott DF, George S, Hammers HJ, Srinivas S, Tykodi SS, Sosman JA, Procopio G, Plimack ER, et al. 2015. Nivolumab versus everolimus in advanced renal-cell carcinoma. $N$ Engl J Med 373: 1803-1813.

Pardoll DM. 2012. The blockade of immune checkpoints in cancer immunotherapy. Nat Rev Cancer 12: 252-264.

Peggs KS, Quezada SA, Chambers CA, Korman AJ, Allison JP. 2009. Blockade of CTLA-4 on both effector and regulatory $\mathrm{T}$ cell compartments contributes to the antitumor activity of anti-CTLA-4 antibodies. J Exp Med 206: 1717-1725.

Quezada SA, Peggs KS, Curran MA, Allison JP. 2006. CTLA4 blockade and GM-CSF combination immunotherapy alters the intratumor balance of effector and regulatory T cells. J Clin Invest 116: 1935-1945.

Quezada SA, Peggs KS, Simpson TR, Shen Y, Littman DR, Allison JP. 2008. Limited tumor infiltration by activated T effector cells restricts the therapeutic activity of regulatory T cell depletion against established melanoma. J Exp Med 205: 2125-2138.

Quezada SA, Simpson TR, Peggs KS, Merghoub T, Vider J, Fan X, Blasberg R, Yagita H, Muranski P, Antony PA, et al. 2010. Tumor-reactive $\mathrm{CD}^{+}{ }^{+} \mathrm{T}$ cells develop cytotoxic activity and eradicate large established melanoma after transfer into lymphopenic hosts. J Exp Med 207: 637650.

Reck M, Rodríguez-Abreu D, Robinson AG, Hui R, Csôszi T, Fülöp A, Gottfried M, Peled N, Tafreshi A, Cuffe S, et al. 2016. Pembrolizumab versus chemotherapy for PD-L1- 
positive non-small-cell lung cancer. $N$ Engl J Med 375: $1823-1833$.

Rittmeyer A, Barlesi F, Waterkamp D, Park K, Ciardiello F, von Pawel J, Gadgeel SM, Hida T, Kowalski DM, Dols MC, et al. 2017. Atezolizumab versus docetaxel in patients with previously treated non-small-cell lung cancer (OAK): A phase 3, open-label, multicentre randomised controlled trial. Lancet 389: 255-265.

Rizvi NA, Hellmann MD, Snyder A, Kvistborg P, Makarov V, Havel JJ, Lee W, Yuan J, Wong P, Ho TS, et al. 2015. Mutational landscape determines sensitivity to PD-1 blockade in non-small cell lung cancer. Science 348: $124-128$.

Robert L, Tsoi J, Wang X, Emerson R, Homet B, Chodon T, Mok S, Huang RR, Cochran AJ, Comin-Anduix B, et al. 2014. CTLA4 blockade broadens the peripheral T-cell receptor repertoire. Clin Cancer Res 20: 2424-2432.

Robert C, Long GV, Brady B, Dutriaux C, Maio M, Mortier L, Hassel JC, Rutkowski P, McNeil C, Kalinka-Warzocha E, et al. 2015a. Nivolumab in previously untreated melanoma without BRAF mutation. N Engl J Med 372: 320330.

Robert C, Schachter J, Long GV, Arance A, Grob JJ, Mortier L, Daud A, Carlino MS, McNeil C, Lotem M, et al. 2015b. Pembrolizumab versus ipilimumab in advanced melanoma. N Engl J Med 372: 2521-2532.

Robbins PF, El-Gamil M, Li YF, Kawakami Y, Loftus D, Appella E, Rosenberg SA. 1996. A mutated $\beta$-catenin gene encodes a melanoma-specific antigen recognized by tumor infiltrating lymphocytes. J Exp Med 183: 11851192.

Robbins PF, Lu YC, El-Gamil M, Li YF, Gross C, Gartner J, Lin JC, Teer JK, Cliften P, Tycksen E, et al. 2013. Mining exomic sequencing data to identify mutated antigens recognized by adoptively transferred tumor-reactive $\mathrm{T}$ cells. Nat Med 19: 747-752.

Rosenberg JE, Hoffman-Censits J, Powles T, van der Heijden MS, Balar AV, Necchi A, Dawson N, O’Donnell PH, Balmanoukian A, Loriot Y, et al. 2016. Atezolizumab in patients with locally advanced and metastatic urothelial carcinoma who have progressed following treatment with platinum-based chemotherapy: A single-arm, multicentre, phase 2 trial. Lancet 387: 1909-1920.

Sharma P, Retz M, Siefker-Radtke A, Baron A, Necchi A, Bedke J, Plimack ER, Vaena D, Grimm MO, Bracarda S, et al. 2017. Nivolumab in metastatic urothelial carcinoma after platinum therapy (CheckMate 275): A multicentre, single-arm, phase 2 trial. Lancet Oncol 18: 312-322.

Simpson TR, Li F, Montalvo-Ortiz W, Sepulveda MA, Bergerhoff K, Arce F, Roddie C, Henry JY, Yagita H, Wolchok JD, et al. 2013. Fc-dependent depletion of tumor-infiltrating regulatory $\mathrm{T}$ cells co-defines the efficacy of antiCTLA-4 therapy against melanoma. J Exp Med 210: 1695-1710.

Snyder A, Makarov V, Merghoub T, Yuan J, Zaretsky JM, Desrichard A, Walsh LA, Postow MA, Wong P, Ho TS, et al. 2014. Genetic basis for clinical response to CTLA-4 blockade in melanoma. $N$ Engl J Med 371: 2189-2199.

Seiwert TY, Burtness B, Mehra R, Weiss J, Berger R, Eder JP, Heath K, McClanahan T, Lunceford J, Gause C, et al. 2016. Safety and clinical activity of pembrolizumab for treatment of recurrent or metastatic squamous cell carcinoma of the head and neck (KEYNOTE-012): An openlabel, multicentre, phase 1b trial. Lancet Oncol 17: 956965.

Tran E, Turcotte S, Gros A, Robbins PF, Lu YC, Dudley ME, Wunderlich JR, Somerville RP, Hogan K, Hinrichs CS, et al. 2014. Cancer immunotherapy based on mutationspecific $\mathrm{CD} 4^{+} \mathrm{T}$ cells in a patient with epithelial cancer. Science 344: 641-645.

Tumeh PC, Harview CL, Yearley JH, Shintaku IP, Taylor EJ, Robert L, Chmielowski B, Spasic M, Henry G, Ciobanu V, et al. 2014. PD-1 blockade induces responses by inhibiting adaptive immune resistance. Nature 515: 568-571.

Van Allen EM, Miao D, Schilling B, Shukla SA, Blank C, Zimmer L, Sucker A, Hillen U, Geukes Foppen MH, Goldinger SM, et al. 2015. Genomic correlates of response to CTLA-4 blockade in metastatic melanoma. Science 350: 207-211.

van der Bruggen P, Traversari C, Chomez P, Lurquin C, De Plaen E, Van den Eynde B, Knuth A, Boon T. 1991. A gene encoding an antigen recognized by cytolytic $\mathrm{T}$ lymphocytes on a human melanoma. Science 254: 1643-1647.

van Rooij N, van Buuren MM, Philips D, Velds A, Toebes M, Heemskerk B, van Dijk LJ, Behjati S, Hilkmann H, El Atmioui D, et al. 2013. Tumor exome analysis reveals neoantigen-specific T-cell reactivity in an ipilimumabresponsive melanoma. J Clin Oncol 31: e439-442.

Walunas TL, Lenschow DJ, Bakker CY, et al. 1994. CTLA-4 can function as a negative regulator of $\mathrm{T}$ cell activation. Immunity 1: 405-413.

Wölfel T, Hauer M, Schneider J, Serrano M, Wölfel C, Klehmann-Hieb E, De Plaen E, Hankeln T, Meyer zum Büschenfelde KH, Beach D. 1995. A p16 ${ }^{\mathrm{INK} 4 \mathrm{a}}$-insensitive CDK4 mutant targeted by cytolytic T lymphocytes in a human melanoma. Science 269: 1281-1284.

Zaretsky JM, Garcia-Diaz A, Shin DS, Escuin-Ordinas H, Hugo W, Hu-Lieskovan S, Torrejon DY, Abril-Rodriguez G, Sandoval S, Barthly L, et al. 2016. Mutations associated with acquired resistance to PD-1 blockade in melanoma. N Engl J Med 375: 819-829.

Zhou J, Dudley ME, Rosenberg SA, Robbins PF. 2005. Persistence of multiple tumor-specific T-cell clones is associated with complete tumor regression in a melanoma patient receiving adoptive cell transfer therapy. J Immunother 28: 53-62.

Zimmer L, Goldinger SM, Hofmann L, Loquai C, Ugurel S, Thomas I, Schmidgen MI, Gutzmer R, Utikal JS, Göppner D, et al. 2016. Neurological, respiratory, musculoskeletal, cardiac and ocular side-effects of anti-PD-1 therapy. Eur J Cancer 60: 210-225. 


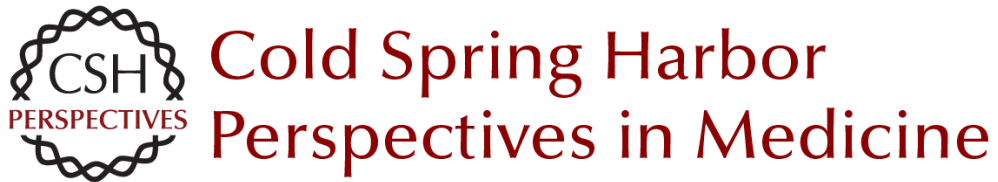

\title{
The "Achilles' Heel" of Cancer and Its Implications for the Development of Novel Immunotherapeutic Strategies
}

\author{
Kroopa Joshi, Benjamin M. Chain, Karl S. Peggs and Sergio A. Quezada
}

Cold Spring Harb Perspect Med 2018; doi: 10.1101/cshperspect.a027086 originally published online June 19, 2017

\section{Subject Collection Cancer Evolution}

The Evolution and Ecology of Resistance in

Cancer Therapy

Robert A. Gatenby and Joel S. Brown

Big Bang Tumor Growth and Clonal Evolution Ruping Sun, Zheng Hu and Christina Curtis

Observing Clonal Dynamics across

Spatiotemporal Axes: A Prelude to Quantitative

Fitness Models for Cancer

Andrew W. McPherson, Fong Chun Chan and Sohrab P. Shah

Evolution of Premalignant Disease Kit Curtius, Nicholas A. Wright and Trevor A. Graham

The Role of Aneuploidy in Cancer Evolution Laurent Sansregret and Charles Swanton

Treatment-Induced Mutagenesis and Selective Pressures Sculpt Cancer Evolution Subramanian Venkatesan, Charles Swanton, Barry S. Taylor, et al.

Chromosomal Instability as a Driver of Tumor Heterogeneity and Evolution Samuel F. Bakhoum and Dan Avi Landau

Coevolution of Leukemia and Host Immune Cells in Chronic Lymphocytic Leukemia

Noelia Purroy and Catherine J. Wu
The Evolution and Ecology of Resistance in

Cancer Therapy

Robert Gatenby and Joel Brown

Phylogenetic Quantification of Intratumor Heterogeneity

Thomas B.K. Watkins and Roland F. Schwarz

The "Achilles' Heel" of Cancer and Its Implications for the Development of Novel Immunotherapeutic

Strategies

Kroopa Joshi, Benjamin M. Chain, Karl S. Peggs, et al.

Homeostasis Back and Forth: An Ecoevolutionary

Perspective of Cancer

David Basanta and Alexander R.A. Anderson

Principles of Reconstructing the Subclonal

Architecture of Cancers

Stefan C. Dentro, David C. Wedge and Peter Van LOO

Tumor Microenvironment and Differential

Responses to Therapy Eishu Hirata and Erik Sahai

Order Matters: The Order of Somatic Mutations Influences Cancer Evolution David G. Kent and Anthony R. Green

The Cellular Origin and Evolution of Breast Cancer Mei Zhang, Adrian V. Lee and Jeffrey M. Rosen

For additional articles in this collection, see http://perspectivesinmedicine.cshlp.org/cgi/collection/ 